\title{
INDONESIA'S TAX AMNESTY LAW BASED ON THE PERSPECTIVE \\ OF \\ THE LAW AS AN ALLOCATIVE SYSTEM
}

\author{
Agus Darmawan \\ Ministry of Finance, Government of Indonesia \\ Candidate Doctoral in Law, Padjadjaran University \\ Email: agus.gic@gmail.com
}

\begin{abstract}
This study aimed to evaluate academic on Law Number 11 of 2016 on the Tax Amnesty as the law as an allocative system approach as presented Lawrance M. Friedman. This study uses a normative approach. The results showed that the Law on Tax Amnesty academically has fulfilled the legal criteria for allocative as intended by Friedman. Tax Amnesty Program is the elimination of the tax owed should not sanction tax administration and criminal sanctions in the area of taxation by way of uncovering treasures and pay the ransom. Tax amnesty aimed to increase tax revenues in the State Budget, which is expected to be more sustainable State Budget to finance development programs for the welfare of all the people of Indonesia.
\end{abstract}

Keywords: law, allocative system, and tax amnesty.

\section{A. INTRODUCTION}

The enactment of Law No. 11 Year 2016 About Tax Amnesty on July 1, 2016 to reap the pros and cons of all Indonesian people. Most people consider tax amnesty program too hasty to be implemented, but there is also considered that this policy should be implemented immediately in view of the condition of the country that require sizeable funding for the implementation of development while tax revenues have not reached the targets set in the state budget. Pros and cons in the community related to tax amnesty policy is reasonable, considering the implementation of tax amnesty in some countries, there are successful and failed. Countries that successfully implement this policy such as : Brazil, India, Italy and South Africa, while an example of the failed state in the implementation of the tax amnesty program is Philippines. 
The definition of tax amnesty in Article 1 of the Law of Tax Amnesty is the elimination of the tax owed which should not get the sanction of the administration tax and criminal sanctions in the area of taxation by a way of uncovering treasures and pay the ransom as stipulated in this law. To provide a better understanding of tax amnesty as stipulated in the Law on Tax Amnesty, some experts give an understanding of the definition of tax amnesty as follows:

1. Tax amnesty is " a limited-time offer by the government to a specified group of taxpayers to pay a defined amount, in exchange for forgiveness of a tax liability (including interest and penalties), relating to a previous tax period(s), as well as freedom of legal prosecution" (Baer dan LeBorgne, 2008:121).

2. Tax amnesty defined as "the possibility of paying taxes in exchange for the forgiveness of the amount of the tax liability (including interest and penalties), the waiver of criminal tax prosecution, and limitations to audit tax determinations for a period of time” (Malherbe, Bulletin for International Taxation, April 2010:224).

Based on the opinions described by Baer, LeBorgne and Malherbe, it can be concluded that the tax amnesty policy is aimed at the elimination of administrative sanctions such as fines and interest taxes, and also includes the elimination of criminal sanctions. Tax amnesty is a limited by time opportunity in certain groups of taxpayers to pay a certain amount and in a certain time in the form of remission of tax liability (including interest and penalties) relating to previous tax period or a certain period without fear of criminal prosecution. This usually ends when the authorities started investigations tax taxes the past. In some cases, the amnesty laws which extend also imposes a harsher penalties on those who are eligible for amnesty but do not take it. This understanding is consistent with that contained in the Tax Amnesty Law.

Tax amnesty program ever enacted in Indonesia by Presidential Decree Number 26 of 1984 which was later changed to the Presidential Decree Number 72 of 1984 . The tax amnesty program at the time is expected is expected to raise awareness of the taxpayers to pay taxes. However, the tax amnesty program at the 
time it was not effective and not many taxpayers who use the program. Then in 2016 in the era of President Joko Widodo, the state of the pros and cons in the community, the tax amnesty program tried to revive with economic considerations that the capital owned by the tax payer were accommodated abroad will go back to Indonesia to boost national economy significantly through development financing productive sectors. It is interesting to consider how the effectiveness of the tax amnesty program which re-launched by the Government of Indonesia in 2016.

Lawrance M. Friedman wrote on his book The Legal System: A Social Science Perspective, stating that the law is what the output generated by the law as a response to social demands. Every day there are millions of demands on the legal system, there are also millions of response. However, we can talk about output and response as things are very common. According to Friedman (1975: 17), which outputs common overall functions of the law. The scope of the law manifested in three forms: (i) Institutions, (ii) Norms), and (iii) Functions. It arises because there is still the definite understanding of the law and still varying legal sense of the jurists. classification into several groups reflect differences in the perception of law and the different purposes for legal writing.

Law in the sense functions is to achieve justice both in the form of distributive justice as well as commutative justice. Then, the law should also serve as a settlement of a dispute and as social control.

Law as a system has a function to distribute and maintain allocation values are correct according to the community. This allocation, which is embedded with the understanding of the truth is what is generally referred to as justice. Aristoteles draw a distinction between distributive justice and commutative justice, the principle of which wealth and honor allocated among citizens and with respect to individual and lawsuits. Among the concepts of justice are ideas on how to bring together people with what he deserves to get, in terms of ethical, no more and no less.

Based on the common knowledge, a justice produced by the legal system can not be defined and it became to be the subject of a broad philosophical 
literature. The public expects the law to meet the standards of ethical and community values based on how the law treats people and how the law of distributing profit and loss.

In the context of the law as an allocative system as presented Friedman, should also be implemented in Indonesia for the formulation of legislation in accordance with its objectives, including the Law on Tax Amnesty, this legislation aims to: i) accelerate growth and economic restructuring through the transfer of property, which increased domestic liquidity, improvement of the rupiah, lower interest rates, and increased investment; ii) encouraging tax reforms towards a more equitable tax system and the expansion of the data base of taxation more valid, comprehensive, and integrated; and iii) increase tax revenues to finance the construction. However, the question is whether the Tax Amnesty Law can achieve its objectives. It requires a legal review of the tax amnesty law, which include: how it performs?; how it treats people?; how it distribute?; and how its cost and benefit? as Friedman's concept of law as a allocative system.

From the background as described above, this study will review the effectiveness of Tax Amnesty Act which was enacted on July 1, 2016 in terms of the concept of "Law as a Allocative System" presented by Friedman.

\section{B. PROBLEM STATEMENT}

How the effectiveness of Act Number 11 of 2016 on Tax Amnesty which was enacted on July 1, 2016 in terms of the concept of "Law as an Allocative System" presented by Friedman?

\section{RESEARCH METHODS}

The nature of the research in this paper is descriptive conducted with normative juridical approach. The types and sources of data used are secondary data. The data collection was done by library research and online research with the necessary inventory of secondary data, either in the form of primary, secondary and tertiary legal materials, and then perform a search history and 
synchronization between the legal material. Primary legal materials used consist of legislation, especially related to tax amnesty program. Secondary legal materials used include: scientific papers, studies and literature relating to the substance of the research. Tertiary legal materials used are materials that support the information of primary and secondary legal materials, including: data from newspapers, journals, dictionaries, encyclopedias.

\section{DISCUSSION}

\section{Perspective Legal System According to Friedman Thought}

Friedman stated that the scope of the law manifested in three forms: (i) institutions, (ii) norms, and (iii) Function. It arises because there is still the definite understanding of the law and still varying legal sense of the jurists, can be classified into several groups, reflecting differences in the perception of legal and goal difference in the formulation.

Law as a system has a function such as to distribute and to maintain allocation correct values according to the community. This allocation, which is embedded within the understanding of the truth in which is generally referred to as justice. Aristoteles draw a distinction between distributive justice and commutative justice, the principle of which wealth and honor allocated among citizens and with respect to individual and lawsuits. In the midst of the concept of justice are ideas on how to bring together people and what they deserve, in terms of ethical, no more and no less.

Regarding the scope of the Institutional in many communities, there are people and institutions in the ordinary part of the legal system. However, we can establish a definition around the professionals and institutions, and as a result the legal system here is limited by the relevant profession of lawyers, judges, police, legislators, administrators, notaries and others

Regarding the norm, the law also includes what is called a set of rules. In a legal system that is sacred, 'law' is a collection of sacred norms and not more than that. Other legal experts regard the law as rules or norms that are not necessarily official nature, they emphasize customs grounding in law, namely the patterns of 
actual behavior. Michael Barkun stated that law in the shared norms of a society which has rules about rights and obligations. Eugen Ehrlich made the term 'living law' to describe the actual behavior patterns in a community. Bronislaw Malinowski found that the law contained in the patterns of behavior which was run by way of reciprocity. In the Indonesian context, the law as the norm can be seen from the provisions of various laws and regulations.

, in line with the scope of norms, regarding function, definitions are avoided wherever possible law of definitions related to government or state. In this case, the law is defined as the definitions formulated in accordance with the law of portraying functions. One of its functions is the settlement of disputes. We can also call that every aspect of society and every institution that run social control is an aspect that is legal. Functional definitions are useful in comparing cultures by law. The institutions whose names are different can execute the same functions and the same institution or roles can have very different functions in different societies.

The legal system is not the only one in this case, each sub-system in the community has its own function or mission. In most general level, the legal system has a function such as to distribute and to maintain allocation correct values according to the community. This allocation, which is embedded with the understanding of the truth, is what is generally referred to as justice. Aristotle (Stone, 1965: 14), draws a distinction between distributive justice and commutative justice, the principle of which wealth and honor allocated among citizens and with respect to individual and lawsuits. In the midst of the concept of justice are ideas on how to bring together people in terms of what they deserve, viewed ethically-no more and no less. How to run it is a problem that has been cultivated by the law philosophers for centuries. Here we encounter the idea only as a sociological fact as the mandate given to the relevant public with the legal system. In other words, the legal system is supposed to guarantee the correct distribution or right among people and groups. In the lawsuits and the individual transaction, the system should apply the correct rules or right (or perhaps the most comfortable) 
Another function of the legal system is as dispute resolution. Conflicts arise in any society. One of the principal functions of the law is to provide a machine and that can be addressed by the people to resolve their conflicts and disputes completed them. This function is not monopolized by the legal system, but there are other functions that exist in society.

The other functions of the legal system is social control. Basically, the legal system is a form of enforcement of the rules regarding the correct behavior. The cops and judges know that thieves should be arrested and sent to prison. We can call the criminal law as the primary social control. Meanwhile, secondary social control is advised, give lessons, rehabilitate equally important. Thieves are caught and brought to justice is not solely controlled; he was also "a lesson" (whether that lesson will be successful or not, is another matter). Courts around the world acting or attempting to act as a moral teacher, reformer, and offender rehabilitation

Another function of the law is to create it's own norms, raw materials for social control. Social forces catapult pressures; these demands "make up" the law, but the institutions that exist in the legal system reap the demands it, crystallize and turn them into rules, principles, and instructions for civil servants and the general population. In carrying out and move it, the legal system can act as an instrument of change.

The functions that Friedman presented in the above description is simple and real. In addition, it is possible for law, legal proceedings, and legal systems to perform the other functions that is not too flashy. Law expresses and defines the norms of society. It's not the same to teach and preach the function of the law, because these functions have an instrumental purpose is to change behavior. In other words, the law and the regulations announced what criterion and confirms that people can and will punish the perpetrators of these acts exceed the limit. The goal is not to press in order to bring order, even though it may be the ultimate goal, but rather press in norm-morma decorate public awareness.

Law as an allocative system as presented Friedman can be used to test the effectiveness of the law. In the context of the tax amnesty law that was promulgated in Indonesia on July 1, 2016 which raised the pros and cons in the 
community, could also use the concept of law as an allocation system to test its effectiveness. In practice, testing the effectiveness of laws tax amnesty use multiple indications, namely: how it performs ?; how it treats people ?; how it distribute ?; and how its cost and benefit?.

\section{Performance of Tax Amnesty Law (“How it Performs?")}

H.L.A. Hart argues that the characteristics of a dual legal system is a collection of rules. A legal system is the unity of the 'rules of the primary' and 'secondary rules'. Regulation is the primary behavioral norms, while the secondary legislation is the norm on these norms, how to decide whether they were valid, how to apply them, and others. Both primary and secondary legislation is equally output of a legal system. On the whole it is a way to explain the behavior of the legal system when viewed in cross. The litigants will behave on the basis of the substance that led to forecasts that they responded. In this regard, Law on Tax Amnesty should reflect an output that is able to increase awareness and compliance community in implementing the tax obligations on the property in the country or abroad to be reported fully in the Annual Tax Income in order to increase tax revenue as financing national development for the welfare of all the people of Indonesia.

Historically, tax amnesty in Indonesia has been implemented in 1964 through President Determination Number 5 of 1964 Concerning the Rules of Tax Amnesty. The contents of the regulation is that the tax amnesty program is intended for the benefit of the Indonesian national revolution and national development and to facilitate the implementation of the Economic Declaration on 28 March 1963. In that time tax amnesty program, granted remission of taxes on capital are in a society that has not been taxed company tax, income tax and wealth tax are registered with the Directorate General of Taxes prior to August 17, 1965. The tax amnesty program can not become an excuse for the fiscal agency or legal authority to conduct the investigation and examination of the capital which became the object of tax amnesty. The capital levy imposed one by 10 percent to 
compensate foregone taxes. Subsequently, in 1984 has also been issued a tax amnesty program, namely through the Presidential Decree Number 26 of 1984. The tax forgiveness is granted on taxes which have never been or have not been entirely charged or levied in accordance with the legislation in force. Implementation of the tax amnesty program when it is not effective because the taxpayer is not too respond and not followed by reform of the tax administration system as a whole. In addition, the role of the tax sector in the state budget system is still functioning as complementary, so that the government does not seek earnestly for the success of the tax amnesty program at the time.

In the Tax Amnesty Law, explained that the success of national development is strongly supported by funding from tax payment receipts. Then, in order of receipt of payment of tax can be distributed evenly without any discrimination, is necessary to create a more equitable tax system and a legal certainty through tax amnesty policy. Tax amnesty program conducted in the form of a waiver the state to collect taxes that should be owed. Therefore, the taxpayer is required to pay a ransom for the forgiveness of tax obtained. Acceptance of the ransom is treated as income tax revenue in the state budget.

Theoretically, the tax amnesty policies is relevant to the terms of discretion on enforcement in the field of administration. Discretion is the decision and/or action defined and/or implemented by government officials to address the issue of the concrete facing in governance in terms of legislations that provide choice, not regulate, incomplete or unclear, and/or stagnation of government, the aim of the tax amnesty policy such as: i) raising awareness of the taxpayer for more compliant in the future; ii) increase the number of taxpayers, both the ratio and the amount of numbers, so that potentially could increase state revenue tax sector; iii) to collect taxes that are not yet collected in prior periods; and iv) to improve the recording of data and information on the taxpayer and the tax obligations, so surveillance against possible violations of tax is to provide legal certainty for the obligations of the taxpayer, which can reduce fears of the onset of more severe sanctions in the future (Summers, 1987 : 125). However, it should be a concern and vigilance of government is with regard to the possibility of misuse 
of the program of tax amnesty to carry out money laundering as ever in Bangladesh (Attiya, et al., Journal of Money Loundering Control, Vol. 17, Issue . 1, 2014: 56)

Empirically, the implementation of tax amnesty programs in some countries there are successful and some are experiencing failures. Some countries have managed to implement a tax amnesty program, such as: India, South Africa, Brazil and Italy. The success of the tax amnesty program of these three countries, is that the tax amnesty program initiated followed by regulatory and taxation system also enhanced. On the contrary, some countries that failed in the tax amnesty program because of regulatory and tax system that does not support the program and the lack of readiness of tax administration related to the management of information data on tax amnesty. So that taxpayers who participated remission of tax can not be monitored for compliance behavior of post tax amnesty program ends. According Ner (International Journal of Economics and Financial Issues, Vol.5 (2), 2015: 37), is necessary to create a sense of justice for the taxpayers obedient so do not turn out to be non-compliant taxpayers. Things to avoid is the perception that the tax amnesty program is a program dedicated to the noncompliant taxpayers.

Tax amnesty program in Indonesia should be applied, considering if it is not implemented in the near future, Indonesia threatened not to add a base of new taxpayers. It is necessary to be taken into consideration that the era of the Automatic Exchange of Information (AEOI) will soon begin in 2018. The AEOI at this moment should be utilized by the government.

Tax amnesty program conducted in several countries which are tailored to the tax system show that the tax amnesty program need to see the conditions that occur in the community, in this case regarding the purpose of the application of the tax amnesty program. Law is a set of norms sacred and nothing more than that. Other experts viewing the law as rules or norms that does not necessarily mean an official nature; they emphasize customs grounding in law, namely the actual patterns. In his research, Barkun (1968: 92) find their legal norms which does not necessarily mean an official nature; customs, they find grounding in the law, that 
is, patterns of actual behavior. Barkun also find their legal norms along with a "society that has rules about rights and obligations". Meanwhile, Ehrlich (1936: 51-55) makes the term "living law" to describe the actual behavior patterns in society. Opinions that are in line with Ehrlich, also delivered Molinowski (1926: 234) which found that the law contained in the behaviors that run in a "reciprocal".

The background of the establishment of a tax amnesty program is a fundamental economic policy and not solely related to fiscal policy, especially tax moreover. In terms of taxation, the tax amnesty expected revenue potential will increase in the budget so that the budget is expected to be more sustainable. If the state budget has a more sustainable and increased government spending power, it automatically will help the implementation of development programs related to welfare of the Indonesian people. On the other hand, the tax amnesty program is also expected to follow the repatriation of part or all the assets of Indonesia abroad it helps to macroeconomic stability. It is seen from the exchange rate, international reserves, balance of payments and banking liquidity is getting better. Tax amnesty program is very strategic because the macro impact, thorough and fundamental to the Indonesian economy. However, the success of the tax amnesty program in the economic development of a country will be affected by economic liberalization. In economic liberalization, economic actors can invest in any country that is economically profitable and it is becoming a challenge in tax revenue including the implementation of the policy of tax amnesty (Bose and Jetter, 2011: 85)

In performance, the Tax Amnesty Law was strong enough to be implemented, also gave a purpose and a basic stipulation of the law based on economic conditions and the aim to improve the welfare of the community. The program of the tax amnesty stipulated in Law Number 11 of 2016 will be followed by other policies such as the rule of law is more strict and refinement of the Law on General Provisions and Tax Procedures, the Law on Income Tax, Law on VAT value of Goods and Services and Sales Tax on Luxury Goods, as well as 
other strategic policies in the field of taxation and banking, thereby increasing optimism enforcement of this law.

\section{Application of Tax Amnesty Law ("How it Treats People?")}

The structure and substance is the real component of a legal system, but all of the most far just a blueprint or design, not a machine at work. The problem is the traditional structure and substance of all that is static, they are like a still image of a legal system, like a lifeless image and bias. The image was not showing motion and reality. The legal system is described merely as a formal structure and substance is like a silent courtroom as spellbound, frozen and stuck under the spell of immortality odd.

Giver of life and the reality of the legal system is the external social world. The legal system is not isolated or alienated, but he relies implicitly on the inputs from the outside. Without any party-litigants, there will be no trial. Without any problems and the will to get it done, no litigants. All of these social elements to break the ice and move the system

A modern legal system contains regulations immense amounts lots, partly objective and partly discretionary (Friedman, 1967: 786). The proportion between one type and the other type is always changing. Discretionary rules more interesting for jurists; regulations seem primitive or formalistic objective. But even a cursory glance in the books for the legislation of any country showing their thousands objective rules. All of it was a burden to law. Modern law requires regulations carefully. The legal system must ensure that the regulations are in the discretionary appropriate boundaries in order to provide legal certainty. Likewise with the Tax Amnesty Act should also provide legal certainty and does not discriminate in its implementation. According to Rechberger (2010: 37), in the implementation of the tax amnesty program takes the concept of justice for taxpayers who from the beginning has been carrying out the obligations well and do not need to follow the program of forgiveness taxation, thereby preventing good taxpayers to evade taxes in the future. 
In order to guarantee legal treatment is not discriminatory and selective in the implementation of the program of tax amnesty which can be explained that the Law on Tax Amnesty was enacted in an effort to create a tax system more equitable and berkepastian law in the hope of community participation in the payment of taxes for national development. It is based on the still rampant economic activity in the country that have not been or are not reported to the tax authorities. Activities that are not reported to the disturbing sense of justice for taxpayers who have contributed actively in the implementation of tax obligations because the perpetrators do not contribute to the national development funds.

Equal treatment to each taxpayer in the tax amnesty program is an indication that the law is made applicable equally to all citizens in accordance with its obligations, such as: i) setting of the subject of the tax amnesty; ii) tax amnesty arrangements regarding the object; iii) setting the rates and how to calculate the ransom money; iv) arrangements concerning the procedures for submission of an affidavit, certificate issuance, and the remission of tax obligations; v) arrangements regarding the investment obligations to the assets disclosed and reporting; and vi) arrangements regarding taxation treatment.

Readiness of tax administration related to the management of information data on tax amnesty, it is necessary to monitor the taxpayers who participate in the program of tax amnesty to monitor the behavior of compliance wake of a tax amnesty ends, so that a sense of fairness to the taxpayer from the beginning dutifully and correctly report tax obligations and do not get a tax amnesty facilities can be realized (Bose and Jetter, 2011: 102).

\section{Distribution of the enactment of the Tax Amnesty ("How it Distribute?")}

Gusfield (1967: 92) draws a line between the symbolic and the instrumental purpose of a rule or law. A law is instrumental if he focused on the behavior of concrete; Such laws have "little effect" unless strictly enforced. Symbolic law "does not depend on the implementation in order to produce the effect." 
The purpose is the intention of the legislator, is quite difficult to know what is meant by the authorities. Lawmakers may have many different purposes, they say something, but the aim was not it (Friedman, 1967: 56). In the Tax Amnesty Act created with the aim of: i) accelerate growth and economic restructuring through the transfer of treasure, which among other things will have an impact on the increase in domestic liquidity, improvement of the rupiah, lower interest rates, and increased investment; ii) encouraging tax reforms towards a more equitable tax system and the expansion of the data base of taxation more valid, comprehensive, and integrated; and iii) increase tax revenues, among others, will be used to finance the development, implementation must uphold the principles of justice in accordance with the rights and obligations as stated in distributive justice according to Aristotle. According Muttaqin (Indonesian Journal of Dialetics, Vol.1, No. 3, 2011:10), a tax amnesty program is not merely seen in the perspective of "horizontal-vertical justice" but it should be viewed as a transitional justice by taking into account the benefits state in terms of reception, law enforcement and supervision of taxation

Aristoteles draw a distinction between distributive justice and commutative justice, the principle of which wealth and honor allocated among citizens and with respect to individual and lawsuits. In the midst of the concept of justice are ideas on how to bring together people and what they deserve, in terms of ethical, no more and no less.

In order to ensure the implementation of the tax amnesty program, Forgiveness Tax Act prescribes the principles of tax amnesty arrangement that aims to provide justice for the entire taxpayer. The principle of the Tax Amnesty Law is that the tax amnesty granted on the tax obligations that have not or have not been fully resolved by the taxpayer, which is represented in a property that has never been reported in the last income tax returns. The amount of bases ransom is an additional property that has never been reported in the last income tax returns reduced by debt associated with the acquisition of additional assets. 
With the application of the principle as described above, this indicates that the concept of distributive justice is delivered Aristotle applied in the Tax Amnesty Law passed in 2016.

\section{Economic Analysis of Tax Amnesty Law ('How its Cost and Benefit?”)}

Pound outlook on the theory of social interest is an embryonic concept of "law as social engineering" presented at the Conference on "American Society of Sociology of Law" Year 1971. Pound stated that "Looked at functionally, the law is an attempt to reconcile, to harmonize, to compromise or complicating Reviews These overlapping interest, ... so as to give effect to the greatest number of interests that weigh most in our civilization, with the least sacrifice of other interests..I venture to think of problems of eliminating friction and waste in human preculading enjoyment of the goods of existence, and of the legal order as system of social engineering whereby Reviews These ends are Achieved ". Pound's statement expressed a very broad statutory functions including to reconciliation, harmony and compromise of all conflicts of interest in society (individual, public and state), the principle that only for the sake of the most with the smallest sacrifice on behalf of others; that's what he called "the law as social engineering" or "a system of social engineering". Pound said in a statement, it became clearly that the concept of the law is meant by it, is a legal concept of the future that have a clear vision on how to resolve conflicts of interest in public life and its relation to the role of the state and individuals. Pound statement was interpreted by Mochtar Kusumaatmadja in the context of national law in Indonesia that essentially how portray the law as a means of renewal of society (Romly Atmasasmita, 2012: 40).

Opinion Pound then encourage the development of non-legal analysis of the development of the law. Character analysis of economics to law is Richard Posner, who use economics approach based on three principles: value, utility, and efficiency. Posner economic analysis was developed by Robert Cooter and Thomas Ullen, with maximalization principle, equilibrium, and efficiency of the law (Romly Atmasasmita, 2012: 42). 
Posner stated that the law is efficient is the allocation of responsibility among those involved in the activities interact in such a way to maximize the value of joint, or some amount to the same thing, to minimize the cost of joint activities. Efficient law enforcement favor of a process of quality control (quality control assessment) and not simply side with the effectiveness of an emphasis on the sheer quantity. A target of law enforcement will only create bias in the process of nation building counterproductive and even tend to fool the public

Philosophically, economic analisys of law approach in line with the statement of legal experts who say that 'the law is for man, not vice versa'. Here we must understand that the law as an instrument (tool) to achieve something, not as a final destination. Economic analysis of law is a rational choice theory in which individuals can critically determine the best way to achieve its objectives and benefits of the actions (action). Because, the achievement of its objectives, the individual tends to satisfy his personal interest (self-interest), so that sometimes collide with the interests of other individuals. Therefore it takes the laws relating to norms to regulate human behavior. Hence we can conclude that the theory of rational choice to make economic analysis of law entered into part of the philosophy, particularly the philosophy of law. Economic analysis of law in measuring the efficiency of a system of law in this case using economic analysis of law works using economics as a theoretical framework to analyze the rules and laws that are used in a particular community. In summary economic analysis of law is to conclude everything can be reduced in a short phrase "how much should be paid to gain something in order not to get something."

Economic analysis of law is a branch of the realm of legal philosophy. Beverly and MacCormick (Craig (ed), 1998: 54) divides legal philosophy into five parts, including: law as a reason, law as will, law as custom, laws and values, and the latter law as politics. Economic analysis of law into the laws and values. Economic analysis of law has several approaches to achieving this, one of inspiration is utilitarian. This was stated explicitly by Hart (1983: 143), which states that the economic analysis of law is inspired by utilitarianism. The utilitarian approach of the philosophy underlying the formation is not entirely 
economic analysis of law, but the ratio or felicific calculus used Bentham can be a door for economic analysis of law for ever evolving and refined by philosophers and economists in the future.

Regarding the establishment of a Tax Amnesty Act would also need to consider the importance of non-legal analysis as described by Posner, Cutter and Ullen. This concern is also felt Atmasasmita, who expressed doubts the legislators in Indonesia considering the importance of non-legal analysis because most of the largest product in Indonesian law contains a provision of criminal sanctions in it are often counter-productive and did not achieve the original purpose of the establishment of enactment the law.

In order to analyze the cost and benefits of the Tax Amnesty Law will use the theory of Economic Analysis of Law of Posner. Posner economics approach based on three principles, namely value, utility and efficiency of the law (Posner, 1992: 79).

By value, tax amnesty program is the elimination of tax owed which should not get the sanction of administration tax and criminal sanctions in the field of taxation, by uncovering treasure and pay the ransom money. The success of national development is strongly supported by funding from tax payment receipts. Then, in order of receipt of payment of tax can be distributed evenly without any discrimination, is necessary to create a more equitable tax system and legal certainty through tax amnesty policy. An acceptance of the ransom is treated as income tax revenue in the state budget. Tax amnesty program contributes significantly in the provision of funds for financing the national economy.

In utilities, tax amnesty program aims to provide justice for the entire taxpayer. The principle of tax amnesty granted on the tax obligations that have not or have not been fully resolved by the taxpayer, which is represented in a property that has never been reported in the last income tax returns. According to Sawyer, that the remission of tax policy should be done cautiously and carefully in order not misplaced (Sawyer: 2011: 123). 
By efficiency, tax amnesty program is a fundamental economic policy, so it is not solely related to fiscal policy, especially tax moreover. In terms of taxation, with the tax amnesty expected is to increas a potential revenue in the state budget for this year or in later years that would make the budget more sustainable. If the state budget is more sustainable, the government's ability to spend is also getting bigger, so it automatically will help realize development programs not only infrastructure but also improving the welfare of all the people of Indonesia. The tax amnesty program is expected to improve equity, economic growth and national stability towards improving the welfare of all people.

\section{E. CLOSING}

\section{Conclusions}

a. Law Number 11 Year 2016 on Tax Amnesty, in terms of the concept of "Law as an Allocative System" presented by Friedman with some studies related to how it performs ?; how it treats people ?; how it distribute ?; and how its cost and benefit? has met the study, as presented Friedman referred.

b. Tax Amnesty Program regulated in Law Number 11 Year 2016, it is necessary to increase tax revenues in the state budget, so expect the state budget will be more sustainable in order to finance development programs not only infrastructure but also improving the welfare of citizens and increasing equity, economic growth and better stability.

\section{Suggestion}

Implementation of the tax amnesty program should be followed by the preparation of the tax administration and management of data on remission of tax information to monitor tax compliance behavior of post tax amnesty program ends and the improvement of other regulations related to tax amnesty program.

\section{BIBLIOGRAPHY:}

Atmasasmita, Romli, 2012, Integrative Legal Theory, Reconstruction Development Of Legal Theory, and the Theory of Progressive Law, Second Edition, Yogyakarta: Genta Publishing

Attiya, Warris, et al., "The effect of Tax Amnesty on anti-money loundering in Bangladesh", Journal of Money Loundering Control, Vol. 17, Issue. 1, 2014, Bradford:Emerald Group Publishing Limited

Baer, Katherine dan LeBorgne, Eric, 2008, Tax Amnesties: Theory, Trend, and Some Alternatives, Washington:International Monetary Fund, Washington

Barkun, Michael, 1968, Law Without Sanctions, New York:Russel Sage Foundation 
Bose, Pinaki dan Jetter, Michael, "A Tax Amnesty in the contex of a Developing Economy", Journal of Public Economy Theory, Vol 1 (4), 2011, Amsterdam:Elsevier

Craig, Edward, 1998, Philosophy of Law, London: Routledge

Ehrlich, Eugen, Fundamental Principles of the Sociology of Law, 1936

Freidman, Lawrence M.,1967, Legal Rules and the Process of Social Change, 19 Stan. L.Rev

, 1975, The Legal System: A Social Science Perspective, New York:Russel Sage Foundation

Gusfield, Joseph, 1967, Moral Passage: The Symbolic Process in Public Designations of Deviance, 15 Social Problems, New York:Russel Sage Foundation

Hart, H.L.A., 1983, Hart's Postscript, Essays on the Postcript to the Concept of Law, Oxford

Malherbe, Jacques, "Tax Amnesties in the 2009 Landscape", Bulletin for International Taxation, April 2010

Molinowski, Bronislaw, 1926, Crime and Custom in Savage Society, New York:Russel Sage Foundation

Muttaqin, Zainal, "Legal Aspects of Granting Tax Amnesty For Efforts To Increase Revenues from Tax Sector", Indonesian Journal of Dialetics, Vol.1, No. 3, 2011, Bandung:Padjadjaran University

Ner, Mehmet, "The effects of behavioral economics on Tax Amnesty", International Journal of Economics and Financial Issues, Vol.5 (2), 2015, Mersin: Cag University

Posner, Richard A, 1992, Economic Analysis of Law, fourth edition, New York:Little Brown and Company

Rechberger Silvia, et al., "Tax Amnesties, Justice Perceptions and Filing Behavior: A Simulation Study", Journal Law and Policy, Vol. 32, No. 2, 2010, Washington DC:Washington University

Sawyer, Adrian, "Industry Partnership and Targeted Amnesties at Ingrained Evasion-A new approach to an old tax problem", Revenue Law Journal, Vol. 16, Issue 1, 2011, Queensland:Bond University

Stone, Julius 1965, Human Law and Human Justice, New York:Russel Sage Foundation

Summers, L.H., 1987, Tax Policy and the Economy, Cambridge:NBER Book Series 